\author{
CHRISTINE MOISAN-JABLONSKI \\ IHS UKSW, Warszawa
}

\title{
SYMBOLIKA OBRAZU «ALEGORII BOŻEJ OPATRZNOŚCI» Z KLASZTORU SIÓSTR WIZYTEK W KRAKOWIE
}

W klasztorze wizytek na Krowodrzy w Krakowie znajduje się interesujący obraz z XVIII w. (il. 1), przedstawiający „Alegorię Bożej Opatrzności”" Kompozycja wypełnia centralne pole ołtarzyka, przechowywanego na klasztornym korytarzu za klauzurą. U samej góry przedstawienia umieszczono symbol Bożej Opatrzności: oko wpisane w trójkąt i otoczone promieniami. Wokół znaku Bożej Opatrzności znajduje się siedmiu Archaniołów: Rafał, Uriel, Gabriel, Michał, Sealtiel, Jehudiel i Barachiel.

Archaniołowie zostali usytuowani przez Pseudo-Dionizego Aeropagitę w Hierarchii Niebiańskiej w ósmym chórze, pomiędzy Zwierzchnościami i Aniołami². O liczbie siedmiu Archaniołów wspomina Księga Tobiasza (Tb 12,15). W Apokalipsie św. Jana kilkakrotnie mowa jest o „Siedmiu Duchach” oraz „,siedmiu aniołach”, którzy znajdują się przed Bogiem, utożsamianych z siedmioma Archaniołami ${ }^{3}$. Pismo Święte podaje imiona tylko trzech Archaniołów:

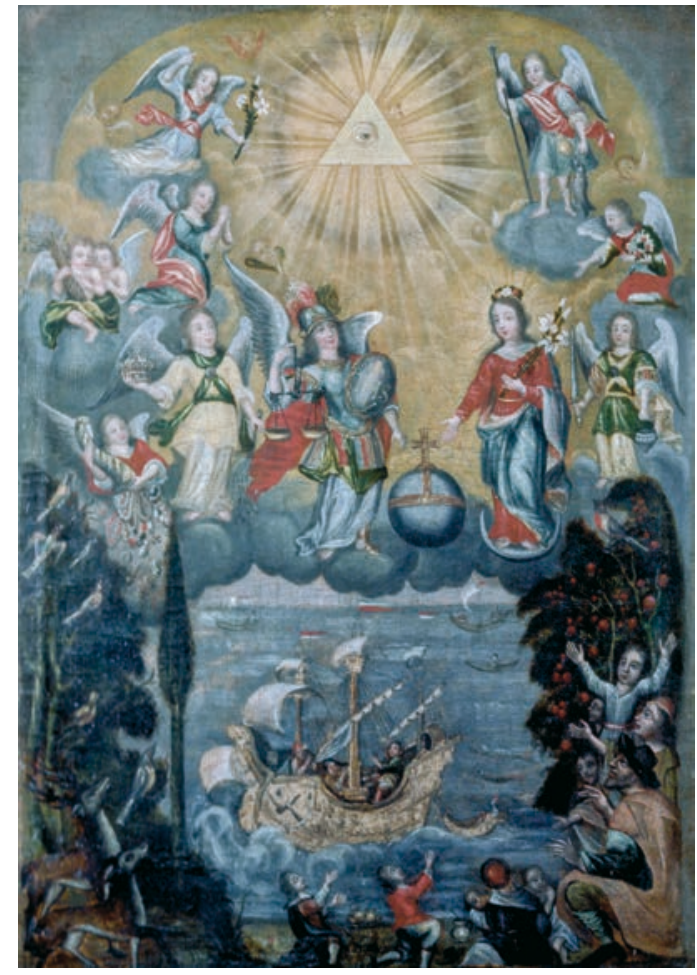

il. 1. Alegoria Bożej Opatrzności, XVIII w., Kraków, Klasztor SS. Wizytek na Krowodrzy, fot. C. Moisan-Jablonski.

\footnotetext{
1 Zbiory Dokumentacji Fotograficznej Instytutu Sztuki PAN w Warszawie. Ołtarz Opatrzności Bożej, 1 poł. XVIII w.

2 G. Davidson, Stownik aniołów w tym aniołów upadtych, tł. J. Ruszkowski, Poznań 1998, s. 57, sub voce „Archaniołowie"; M. Dzielska, Porządek anielski w «Hierarchii niebiańskiej» Pseudo-Dionizego Aeropagity, w: Księga o aniołach, red. H. Oleschko, Kraków 2002, s. 128.

Cytaty według Biblii Tysiaclecia: Łaska i pokój wam od Tego, Który jest, i Który byt i Który przychodzi, i od Siedmiu Duchów, które sa przed Jego tronem (Ap 1,4); To mówi Ten, co ma Siedem Duchów Boga i siedem gwiazd (Ap 3,1); A z tronu wychodza błyskawice i głosy, i gromy, i płonie przed tronem siedem lamp ognistych, które sa siedmiu Duchami Boga (Ap 4,5); I ujrzatem (...) stojącego Baranka, jakby zabitego, a miat siedem rogów i sied-
} 


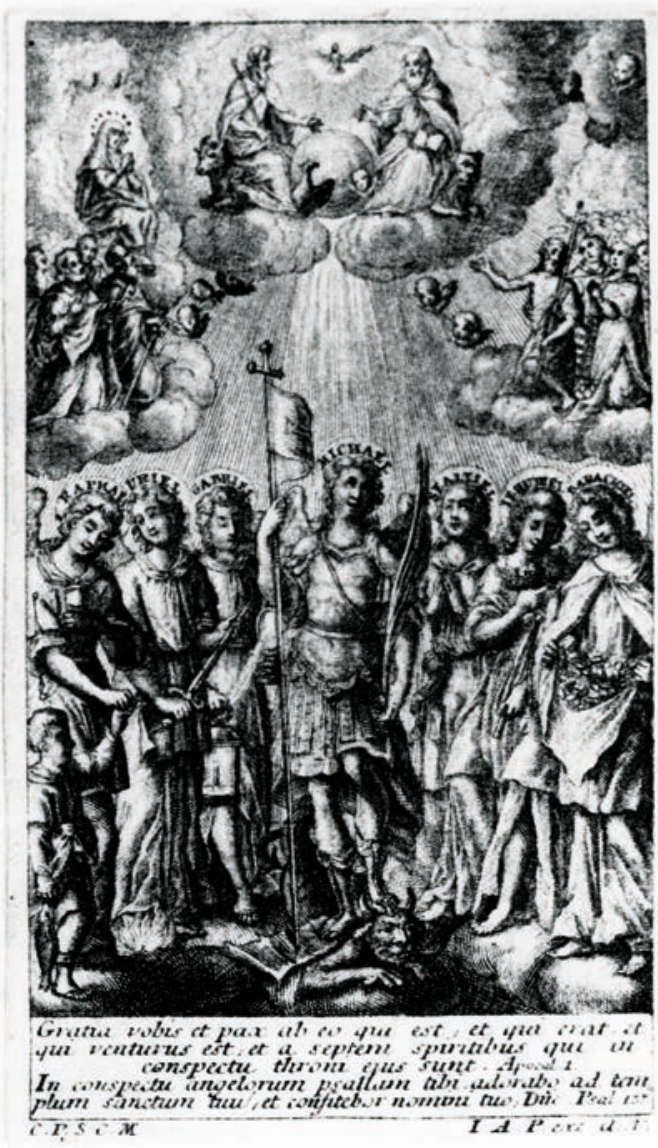

i1. 2. Johann Andreas Pfeffel, Siedmiu Archaniołów, XVIII w., Kraków, Klasztor SS. Karmelitanek Bosych na Wesołej, fot. P. Jaksim-Kirejczyk
Michała, Gabriela i Rafała. Pozostałe imiona spotykamy w różnorodnych księgach apokryficznych ${ }^{4}, \mathrm{w}$ literaturze rabinistycznej, Kabale i pismach gnostyków. W roku 747 Synod Rzymski zakazał używania niekanonicznych imion Archaniołów.

W XV wieku franciszkanin bł. Amadeusz Portugalczyk [wł. Beato Amedeo Menezes de Sylva; łac. w zakonie: Beato Amadeo, w świecie: Ioannes Menesius da Silva], spowiednik papieża Sykstusa IV, twierdził, że doznał objawienia imion siedmiu Archaniołów. Ostatecznie do próby usankcjonowania kultu siedmiu Archaniołów w Kościele rzymsko-katolickim doszło w XVI w. W roku 1516 odkryto w zniszczonym kościele San Angelo Carmelitano w Palermo bizantyjski fresk przedstawiający siedmiu Archaniołów adorujących Trójcę Świętą. Poszczególni niebiescy duchowie byli podpisani i trzymali różnorodne atrybuty5.

Propagatorem nowego typu dewocji był sycylijski kapłan Antonio del Duca [Duca, Lo Duca], między innymi autor Septem principum angelorum orationes cum missa, dzieła poświęconego kultowi siedmiu Archaniołów, którego odmienne wydania ilustrowane rycinami, ukazywały się w oficynach Wenecji, Rzymu i Neapolu'. Do rozpowszech-

mioro oczu, którymi jest siedem Duchów Boga wysłanych na cała ziemię (Ap 5,6); I ujrzałem siedmiu aniołów, którzy stoja przed Bogiem, a dano im siedem trąb (Ap 8,2).

4 H. Oleschko, Aniołowie w apokryfach Starego i Nowego Testamentu, w: Księga o..., s. 374n. Autor zamieszcza pełen spis imion anielskich oraz miejsc ich występowania w apokryfach.

5 Por. E. Mâle, L'art religieux de la fin du XVIe siècle, du XVIIe siècle et du XVIIIe siècle. Étude sur l'iconographie après le concile de Trente. Italie - France - Espagne - Flandres, Paris 1972, s. 299-301; K. Künstle, Ikonographie der christlichen Kunst, t. 1, Freiburg im Breisgau 1928, s. 251; J. B. Knipping, Iconography of the Counter Reformation in the Netherlands. Heaven on Earth, t. 1, Nieuwkoop-Leiden 1974, s. 123-124; E. Lucchesi Palli, Erzengel, [w:] Lexikon der christlichen Ikonographie, red. E. Kirschbaum, t. 1, Rom-Freiburg-Basel-Wien 1968, szp. 677.

6 Należy zaznaczyć, że graficzne przedstawienia nowożytne były inspirowane południowo-italską tradycją o wpływach bizantyńskich utrwaloną w malarstwie freskowym i miniatorstwie XIV-XVI wieku. Szerzej na temat działalności księdza del Duca, por. C. Bernardi Salvetti, S. Maria degli Angeli alle Terme e Antonio Lo Duca, Roma-Parigi-Tournais-New York 1965; J. Talbierska, Grafika XVII wieku w Polsce. Funkcje, ośrodki, artyści, dzieła, 
nienia się kultu przyczynili się początkowo także rzymscy jezuici i filipini ${ }^{7}$. Ogromną rolę w rozpropagowaniu archanielskiej dewocji odegrały także wzorce graficzne: miedzioryty przedstawiające siedmiu Archaniołów rytowane przez Hieronima Wierixa, Pietera de Jode, Joannesa Galle czy Crispijna de Passe Starszego. Ich trawestacje będziemy spotykać jeszcze w XVIII w. ${ }^{8}$ (il. 2).

W Polsce okresu nowożytnego, wyjątkowym, pod względem artystycznym, dziełem poświęconym siedmiu Archaniołom jest cykl miedziorytów rytowanych przez Tomasza Makowskiego (il. 3), przeznaczonych do edycji książkowej. Ta nietypowa seria wydana w roku 1609 w Nieświeżu9 ${ }^{9}$, swą formą i treścią nawiązuje do włoskiego pierwowzoru literackiego, jakim było dzieło Antonia del Duca.

Kult siedmiu Archaniołów nigdy nie został zaaprobowany przez Stolicę Apostolską, a z rzymskich obrazów przedstawiających siedmiu Archaniołów usunięto inskrypcje będące
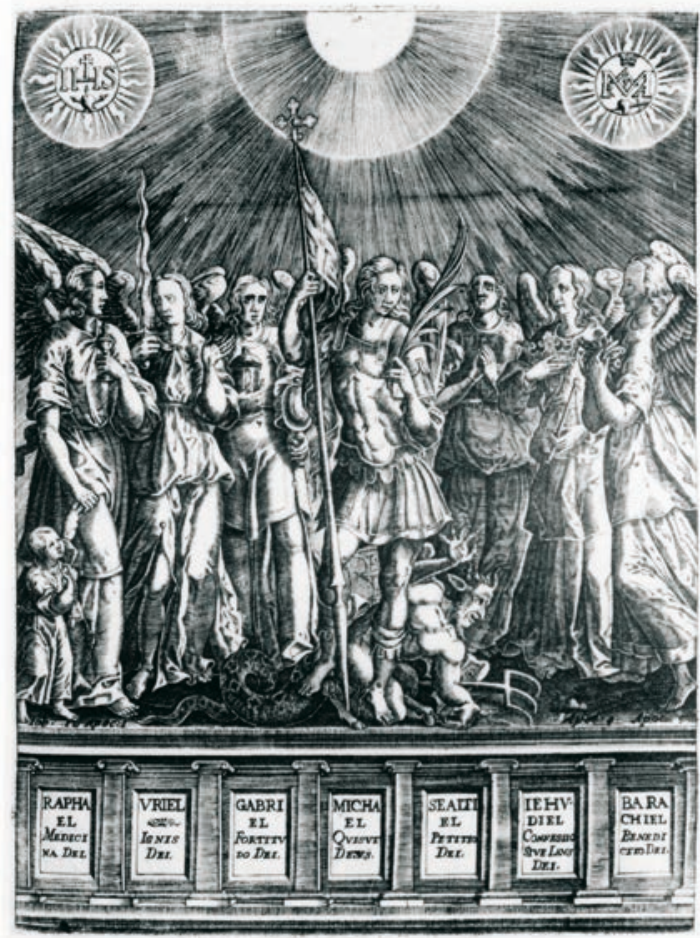

il. 3. Tomasz Makowski, Siedmiu Archaniołów, De Sanctis Angelis Libellus, Nieśwież 1609, Wrocław, Muzeum Książąt Lubomirskich w Zakładzie Narodowym im. Ossolińskich, fot. Ossolineum. imionami czterech niekanonicznych niebieskich duchów: Uriela, Barachiela, Sealtiela i Jehudiela ${ }^{10}$. Pomimo niechęci do nowego typu dewocji, za sprawą piśmiennictwa religijnego

\footnotetext{
Warszawa 2011, s. 117-118, przypisy 142 i 145. Autorka wymienia poszczególne wydania dzieła del Duca oraz zdobiące je przedstawienia.

7 Szerzej na ten temat: T. Johnson, Guardian Angels and the Society of Jesus, w: Angels in the Modern Early World, red. P. Marshall, A. Walsham, Cambridge 2006, s. 191-213; G. A. Bailey, Between Renaissance and Baroque. Jesuit Art in Rome. 1565-1610; Toronto 2003, s. 68-71. Nota bene św. Filipa Neri oraz św. Ignacego Loyolę łączyły więzi przyjaźni z Antonio del Duca, głównym propagatorem archanielskiego kultu.

8 Dla przykładu w zbiorach krakowskiego klasztoru karmelitanek bosych na Wesołej znajduje się rycina wykonana przez Johanna Andreasa Pfeffela, powtarzająca układ kompozycyjny występujący m. in. na odbitce graficznej Hieronima Wierixa. Podobnie jak na sztychu antwerpczyka, także na przedstawieniu wykonanym w XVIII stuleciu w Augsburgu, na nimbach, otaczających głowy siedmiu Archaniołów, umieszczono ich imiona.

9 Szerzej na ten temat: P. Stępień-Kirejczyk, Ikonografia siedmiu Archaniołów w polskiej sztuce i piśmiennictwie religijnym doby baroku, praca magisterska, promotor: C. Moisan-Jablonski, Warszawa 2005, msps [Biblioteka Uniwersytetu Kardynała Stefana Wyszyńskiego w Warszawie], s. 85-93. Rozdział III. 3. „De sanctis Angelis libellus primum Tomasza Makowskiego z 1609 roku"; J. Bednarska, Z dziejów polskiej ilustracji panegirycznej pierwszej połowy XVII wieku, cz. 2, Problematyka stylistyczno-formalna polskiej panegirycznej ilustracji książowej, Katowice 2005, s. 239; Talbierska, op. cit., s. 117-118, 349-350.

10 Mâle, op. cit., s. 298, Knipping, op. cit., s. 124; Bailey, op. cit. s. 70. Słynni współcześni pisarze kościelni, jezuicki teolog Robert Bellarmin oraz hagiograf i oratorianin Cezary Baroniusz, czynili starania by zabronić używania czterech niekanonicznych imion Archaniołów.
} 
i wzorów graficznych wizerunki siedmiu Archaniołów rozpowszechniły się w Europie i w Ameryce Południowej ${ }^{11}$. Z terenów dawnej Rzeczypospolitej, znajdujących się obecnie w granicach Polski, zachowało się kilkanaście przedstawień malarskich i rzeźbiarskich, przede wszystkim powstałych w XVIII w. ${ }^{12}$. Jednym z ciekawszych jest obraz z krakowskiego klasztoru na Krowodrzy.

Każdy z Archaniołów, namalowanych na krakowskim przykładzie, ma odmienny atrybut. Michał Archanioł w hełmie na głowie, odziany w napierśnik, dzierży w prawej ręce wagę. Lewym ramieniem podtrzymuje puklerz, na którym widnieje hierogram IHS zwieńczony krzyżem wraz z umieszczonymi u samego dołu trzema gwoździami. Za wodzem anielskich zastępów stoi Jehudiel z koroną w prawej i biczem w lewej ręce. Ponad nim możemy dostrzec klęczącego Sealtiela, z dłońmi złożonymi w modlitewnym geście. Powyżej rozpoznajemy Archanioła Gabriela dzierżącego białą lilię. Naprzeciwko, po drugiej stronie świetlistego trójkąta, stoi, opierając się na pielgrzymim kiju Archanioł Rafał. Do jego pasa został przytroczony bukłak. W lewej ręce biblijnego opiekuna Tobiasza znajduje się ryba. Poniżej przedstawiono Archanioła Barachiela z kwietnym wieńcem w dłoni, rozrzucającego prawicą białe kwiaty, prawdopodobnie róże. Uriel, ostatni z siedmiu Archaniołów, stoi za plecami Marii. W prawicy dzierży miecz a lewicą podtrzymuje kadzielnicę. Siedmiu Archaniołom towarzyszą trzej inni niebiescy posłańcy. Za pogrążonym w adoracji, klęczącym Sealtielem, znajduje się para aniołów o dziecięcych obliczach. Jeden z nich trzyma snopek zboża. Natomiast u stóp Jehudiela możemy dostrzec anioła wysypującego z rogu obfitości różnorodne kosztowności, symbolizujące także Boże dary i błogosławieństwa.

Większość anielskich atrybutów namalowanych na krakowskim obrazie wymienia jezuita, ojciec Maciej Ignacy Tłuczyński w Anielskiej dobroczynności, która swięci aniołowie z woli Boskiej całemu światu z wielka miłościa wyrzadzaja, wydanej w Krakowie w roku 1677: S. Michała zowia zwycięsca, S. Gabryela, legatem Boskim, S. Rafała, lekarzem. S. Uriela, wiernym pomocnikiem. S. Sealtiela, oratorem to jest krasomowca. S. Jehudiela, widzięcznym. S. Barachiela, konsiliarzem, i różnie ich maluią. S. Michała maluią w prawej ręce maiącego włocznia albo kopija, na wierzchu której jest jasno biała choragiew z czerwonym krzyżem, w lewej ręce ma zielona palme, a pod nogami Lucifer. Inszi z mieczem, i z szala, aby wyrazili najwyższa moc jego, i doskonała sprawiedliwość w rozsadzaniu dobrych i zlych uczynków jako tego który jest najwyższym sędzia po Chrystusie. S. Gabryel bywa malowany tak: zawarta pochodnię w latarni w prawej ręce niesie, a w lewej zwierciadto z jaspisu zielonego. S. Rafat prawa ręka prowadzi Tobiasza młodszego, a w lewej ma skrzyneczkę z ryba. S. Uriel prawa ręka golym mieczem wywija, a lewa ma obwista płomieniem otoczona. S. Sealtiela maluja upokarzającego się, oczy mającego skromnie opuszczone. S. Jehudiel z wesota twarza, w jednej ręce koronę złota trzyma, a w drugiej bicz z trzema czarnymi powrozkami. S. Barachiel z radosna postawa w końcu płaszcza sfałdowanego białe róże pokazuje. Tak

\footnotetext{
11 Bailey, op. cit., s. 70. Autor wymienia m. in. przedstawienia z Boliwii.

12 Por. P. Stępień-Kirejczyk, op. cit., s. 79-147. Tam szersza bibliografia. „Rozdział III. Obraz siedmiu Archaniołów w polskiej sztuce i piśmiennictwie doby baroku. 1. Imiona Archaniołów oraz ich kult w tradycji judeochrześcijańskiej i gnostyckiej; 2. Odrodzenie kultu siedmiu Archaniołów w XVI stuleciu; 3. De sanctis Angelis libellus primum Tomasza Makowskiego z 1609 roku; 4. Siedmiu Archaniołów w piśmiennictwie polskim doby baroku; 5. Siedmiu Archaniołów w polskiej sztuce religijnej; 6. Ikonografia siedmiu Archaniołów".
} 
w Panormie [Palermo, przyp. C. M-J.], i w Antorfie [Antwerpii, przyp. C. M-J.] wymalowani sa ci aniołowie ${ }^{13}$.

Warto zwrócić uwagę, że zgodnie z zaleceniami sztuki potrydenckiej, dotyczącymi sposobu przedstawiania niebieskich duchów, biodra i piersi Archaniołów są przepasane. Zarówno u Gabriela, Sealtiela i Uriela skrzyżowane na piersiach szarfy zostały spięte dekoracyjnymi broszami ozdobionymi szlachetnymi kamieniami. Były one interpretowane przez kontrreformacyjnych teologów jako symbole anielskich cnót, z których najokazalszym klejnotem jest posłuszeństwo $\mathrm{Bogu}^{14}$. Natomiast noszony przez aniołów pas oznacza duchową gotowość do posług, powściągliwość i czystość. Według jezuickiego pisarza Jeremiasza Drexeliusza przepasanie piersi oznacza czystość, którą niebiescy duchowie zachowują w sercu. Z kolei pas otaczający ich biodra można interpretować jako symbol ich cielesnej czystości ${ }^{15}$.

W centrum krakowskiego obrazu, pomiędzy Matką Bożą Niepokalanie Poczętą a Michałem Archaniołem, znajduje się kula zwieńczona krzyżem, symbolizująca świat. Immaculata zgodnie z nowożytną konwencją stoi na półksiężycu i w lewej ręce dzierży lilię. Ubrana jest w czerwoną suknię i niebieski płaszcz, a na jej głowie spoczywa wieniec z białych i czerwonych róż. Gesty Marii i wodza anielskich zastępów, wskazujących dłońmi na glob, pozwalają nam widzieć w nich szczególnych orędowników, polecających ziemię i jej mieszkańców opiece Bożej Opatrzności. Po bokach i u dołu obrazu widnieją ludzie i zwierzęta adorujące Bożą Opatrzność. Niektóre z osób klęczą, wznosząc w błagalnym geście w górę dłonie. Naprzeciwko ludzi, po lewej stronie namalowano jelenia i przyklękającą łanię. Ponad nimi, na gałęziach drzew siedzą różnorodne ptaki.

Pośrodku dolnej części płótna odmalowano morski krajobraz. Na tle niebieskiej toni wyróżnia się żaglowiec z trzema osobami na pokładzie, trzymającymi dłonie złożone do modlitwy. W dali możemy dostrzec płynące łodzie, czasem zaopatrzone w żagiel. Wśród fal widoczne są ryby. Płynący okręt nawiązuje do chrześcijańskiej recepcji tematu navigatio vitae. Jednak wymowę użytych na obrazie symboli tłumaczą przede wszystkim poszczególne zwrotki pochodzące z Pieśni o Opatrzności Boskiej, umieszczonej w zbiorze Pieśni

\footnotetext{
13 M. I. Tłuczyński, Anielska dobroczynność która swięci aniołowie z woli Boskiej całemu światu z wielka miłościa wyrządzaja..., Kraków 1677, s. 381; K. Moisan-Jabłońska, Obrazowanie walki dobra ze złem, Kraków 2002, s. 12-13; P. Stępień-Kirejczyk, op. cit., s. 6, 93-97; poza dziełem Macieja Ignacego Tłuczyńskiego, dwóch autorów jedynie wymienia same imiona siedmiu Archaniołów. Jak zauważa Paulina Stępień-Kirejczyk: „Barokowi kaznodzieje stając wobec faktu rozwijania się kultu archanielskiego, ciągle zakazanego przez Stolicę Piotrową, starali się schrystianizować apokryficzne imiona anielskie, powołując się na przywołany już tekst widzenia błogosławionego Amadeusza”; por. S. Szczepanowski, Kazania świętalne na cały rok..., t. 2, Kraków 1762, s. 174. „Kazanie XXXI. Na Swięty Michał”; W. Odymalski, Świata naprawionego od Jezusa Chrystusa. Historyey Świętej ksiag dziesięć, rytmem stowiańskim wyrażone, b. m. dr., 1670. Księga I, strofa XXX.

14 Por. J. Molani [Molanus, Vermeulen], De historia ss. imaginum et pictorarum pro vero earum usu contra abusus. Libri IV, Antverpiae 1626, s. 350-351. Według Molanusa drogie kamienie umieszczane na piersiach aniołów wskazują na wiek niebieskich duchów oraz oznaczają ich cnoty. Szerzej na temat anielskiej ikonografii: s. 57-58, 343-353. „Liber I. Caput X. Imagines angelorum ex vetustate observatae”. „Liber III. Caput XL. De pictura angelorum, et cur statuae eorum al altaria ponantur”. „Liber III. Caput XLI. Sanctorum angelorum pictura plenius explicantur"; z kolei znany jezuicki teolog Jeremiasz Drexeliusz nawiązując do Ezechielowej wizji odnoszącej się do upadku króla Tyru wspomina, że Lucyfer odrzucił posłuszeństwo, dlatego utracił również pozostałe klejnoty. Por. H. Drexelio, Horologium auxiliaris tutelaris angeli, Coloniae 1631, s. 101. „Horae noctis. V. Hora. Cap. IV”. 15 Drexelio, op. cit., s. 103; szerzej na temat ikonografii rodzimych przedstawień Michała Archanioła i Anioła Stróża por. Moisan-Jabłońska, op. cit., s. 113-165. „Część Pierwsza. Dobro. Rozdział III. Michał Archanioł zwyciężający szatana. Rozdział IV. Anioł Stróż broniący wiernych przed zakusami złego”. Tam szersza bibliografia.
} 
nabożnych wedtug obrzadków Kościoła S. Katolickiego, wydanym pod koniec XVIII stulecia w Królewcu:

Niechaj się na mnie i świat oburzy,

Niech mi niefortuna w żalach zanurzy

Gdy tylko spojrzy niebieskie oko

Wyjdę z tej toni pewnie wysoko (...)

Z Ciebie taknace maja Pasterza

Żywisz po kniejach tak wiele zwierza,

Ptastwo z Twej ręki żywności czeka:

A większy respekt masz na człowieka.

Tyś chorujacym jest za lekarza

Błędnego wiedziesz morzem żeglarza,

Morzem i ziemia ten nie zabłązi,

Którym Twa Boska Opatrzność rządzi ${ }^{16}$.

O opiece nieba wspominają również poszczególne hymny pochodzące z Godzinek o Opatrzności Boskiej, zamieszczonych między innymi w popularnym paulińskim modlitewniku Heroina chrześciańska. Hymn na prymę głosi:

Tyś jest pasterzem taknacych,

Tyś $i$ wodzem jest błądzacych.

Lekarzem tych co choruja,

I gwiazda którzy żeglują.

W hymnie na nieszpor znajdują się słowa:

Opatrujesz żeglujace

I w morzu ryby płynace

Należyta strawę z nieba

Dajac, której im potrzeba.

Natomiast fragmenty hymnów śpiewanych na sekstę i nonę wspominają o opiece nieba nad zwierzętami:

Cóż ta ziemia, co i zorze,

Co $i$ w petnych brzegach morze.

Co wszystkie rzeczy wotaja?

Twa Opatrzność wychwalają. (...)

Co się tu czołga na ziemi,

Co wylatuje nad niemi.

16 Pieśni nabożne wedtug obrządków Kościoła S. Katolickiego sama prostota przyjemne..., Królewiec 1796, s. 322. „Przydatek Nabożnych Pieśni”. 
I co morze w sobie sktada,

Kłaniając Ci się upada ${ }^{17}$.

Podobne myśli odnajdujemy w Pieśni o Boskiej Opatrzności, którą zawiera Officjum codzienne wydane w Supraślu w roku 1799:

Wodne ryby, leśne zwierze,

I powietrzne ptastwo.

Z Twojej ręki żyr swój bierze,

Twoja żyje pastwa ${ }^{18}$.

Widoczny na krakowskim przedstawieniu krajobraz morski obrazuje przede wszystkim Bożą opiekę nad żeglującymi, a także nad żyjącymi w morzu stworzeniami. Również ludzie znajdujący się na lądzie wznoszą błagalnie dłonie, oczekując pomocy od Boga. „Niebieskie oko" Bożej Opatrzności nie zapomina także o zwierzętach leśnych: jeleniu i łani oraz o ukrytych wśród listowia ptakach.

Przedstawienie Bożej Opatrzności z krakowskiego klasztoru wizytek jest dziełem wyjątkowym. Nie możemy jednakże wykluczyć, że anonimowy malarz, tworząc kompozycję, mógł opierać się na nieznanym wzorze graficznym, prawdopodobnie obcej proweniencji. Oryginalna wymowa symboliki obrazu polega na połączeniu przedstawienia Bożej Opatrzności z niekanonicznym motywem siedmiu Archaniołów, na dodatek otaczających Niepokalaną. Nietypowa asocjacja postaci Matki Bożej z siedmioma Archaniołami występująca na płótnie z Krakowa, mogła dokonać się pod wpływem podobnych wizerunków powstałych w kręgu Kongregacji Oratoriańskiej, założonej w Rzymie przez św. Filipa Nereusza. Dla przykładu około roku 1599 Durante Alberti namalował obraz przedstawiający adorację wizerunku Madonny della Vallicella przez siedmiu Archaniołów. Obraz był przeznaczony do rzymskiego kościoła Santi Nereo ed Achilleo ${ }^{19}$.

Ksiądz Maciej Ignacy Tłuczyński, wyjaśniając funkcje pełnione przez każdego z siedmiu Archaniołów, pisał: Pierwszy [Michał, przyp. C. M-J.]: przy Panu Bogu przeciw diabłu stanąt, przeklęty jego związek z nieba wyrzucając. Wtóry [Gabriel, przyp. C. M-J.]: mocnymi racjami z Panna Najśw. szedt, aby zezwolita na macierzyństwo Syna, który jest siła i moca Boska. Trzeci [Rafał, przyp. C. M-J.]: ślepotę Tobiaszowa uleczyt. Czwarty [Uriel, przyp. C. M-J.]: Ludzi przez wnętrzne natchnienia oświeca. Piąty [Sealtiel, przyp. C. M-J.]: Ludzi do moditw zapala. Szósty [Jehudiel, przyp. C. M-J.]: ludzi pobudza do chwalenia P. Boga. Siódmy [Barachiel, przyp. C. M-J.]: błogostawieństwa nam Boskie uprasza i żebyśmy dziękowali P. Bogu za wszystkie dobrodziejstwa naprasza ${ }^{20}$.

Według barokowego kaznodziei funkcję szafarza Bożej Opatrzności zdaje się przede wszystkim pełnić Archanioł Barachiel. Jednak ujmując opiekę Bożej Opatrzności nad ludźmi i światem w szerszym kontekście, należy stwierdzić, że każdy z siedmiu Archaniołów

\footnotetext{
17 Heroina chrześciańska świątobliwemi aktami i wdzięczna rozmaitościa modlitw najprzedniejszych uzbrojona, [Częstochowa] Jasna Góra 1767, s. 90-92. Końcowy fragment „Hymnu na nonę” głosi: Nie ma gniazdo ptaka szkody,/ Choć je sklada w morskie wody./ To jest zimorodek zwany,/ Opatrznościa Twa chowany.

18 Officjum codzienne z różnemi nabożeństwami nowo przydanemi..., Supraśl 1799, s. 360.

19 Bailey, op. cit., s. 70. Malarz wykorzystał w swej kompozycji Maryjny wizerunek znajdujący się w rzymskim kościele filipinów Santa Maria in Vallicella; por. A. Zucchari, La politica culturale dell'Oratorio Romano nelle imprese artistiche promosse da Cesare Baronio, „Storia dell'arte” nr 42 (1981), s. 171-193.

20 Tłuczyński, op. cit., s. 383; Stępień-Kirejczyk, op. cit., s. 143-144.
} 


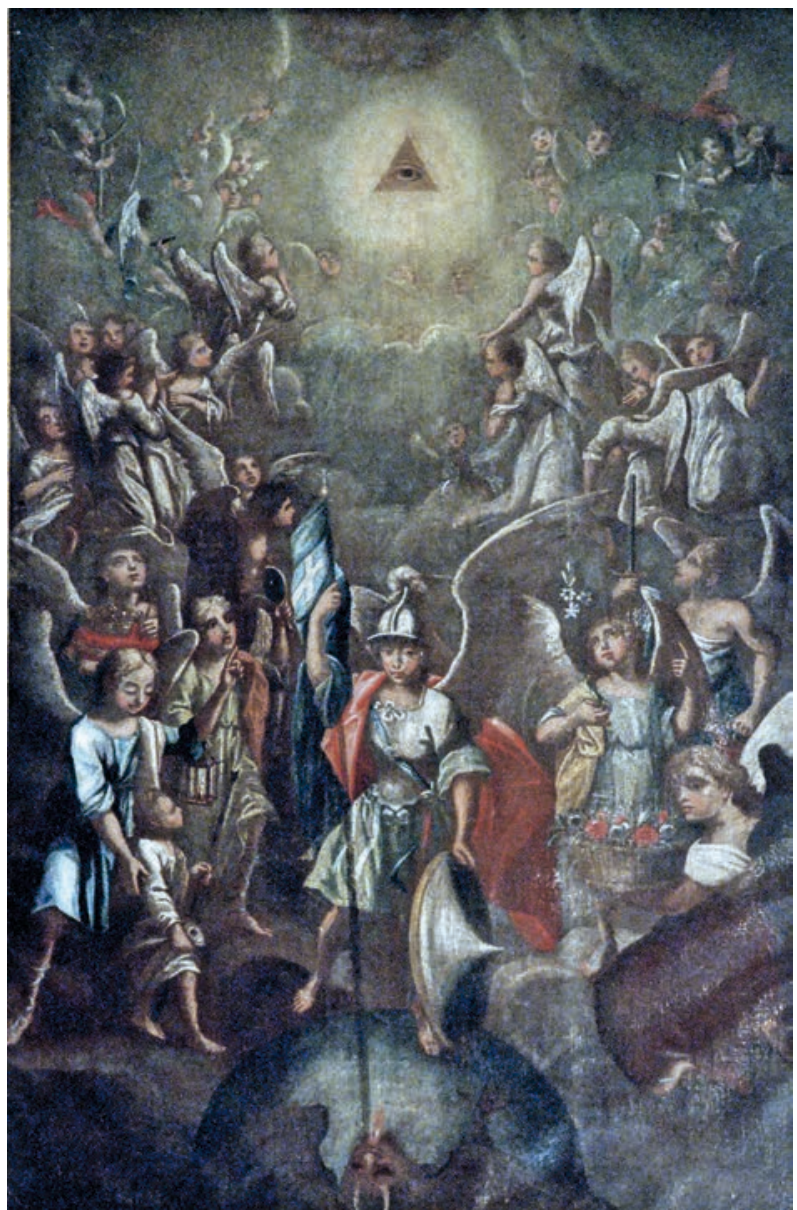

il. 4. Alegoria Bożej Opatrzności, XVIII w., Kaszyce, kościół parafialny, fot. C. Moisan-Jablonski. wraz ze swą wyjątkową misją staje się posłańcem i narzędziem Providentia Dei. Możemy domniemywać, że podobne przekonanie legło u podstaw powstania nietypowego, krakowskiego przedstawienia. Nie sposób nie zauważyć analogii pomiędzy wizją natchnionego autora opisaną w Apokalipsie, mówiącą według staropolskiego tekstu Pisma Świętego przełożonego z łaciny przez księdza Jakuba Wujka $^{21}$ - o siedm anyolow stoiacych przed oczymi Bożemi (Ap $8,2)$, a plastyczną wizualizacją Archaniołów otaczających kręgiem symbol oka Opatrzności na płótnie z klasztoru wizytek.

Należy jednocześnie zaznaczyć, że górna część malarskiego dzieła wykazuje zbieżności kompozycyjne $\mathrm{z}$ polichromią znajdującą się w krużganku klasztornym dawnego kościoła sióstr dominikanek w Piotrkowie Trybunalskim ${ }^{22}$. Górna część malowidła, powstałego prawdopodobnie około lat 1676-1689, także przedstawia adorację oka Opatrzności Bożej przez siedmiu Archaniołów ${ }^{23}$, ukazanych

w tym samym porządku co na płótnie z krakowskiego klasztoru na Krowodrzy. Fakt ten zdaje się potwierdzać istnienie jednego wspólnego wzorca graficznego bądź występowanie kilku rycin o podobnej kompozycji, które mogły pełnić funkcję modeli dla wybranych

21 Biblia to iest Księgi Starego y Nowego Testamentu, wedtug lacinskiego przektadu starego (...) księdza Iakuba Wuyka..., Kraków 1549, s. 1464.

${ }^{22}$ Karta Inwentaryzacyjna Narodowego Instytutu Dziedzictwa [dalej NID], opr. A. Wolska-Rój, (woj. łódzkie), kościół rektorski pw. Matki Bożej Śnieżnej (d. dominikanek), krużganek klasztorny, tempera na tynku. Malowidło wchodzi w skład zespołu 17 malowideł powstałych po odbudowie klasztoru po pożarze w $1648 \mathrm{r}$. i zniszczeniach szwedzkich w 1651 i 1657 r. Zamalowane w 1869 r., odsłonięte w 1. 1952-1953.

23 Dolna część polichromii przedstawia scenę Ukrzyżowania. Dokładna analiza ikonograficzna obrazu, por. Stępień-Kirejczyk, op. cit., s. 96-98, il. 79. Jak zauważa Stępień-Kirejczyk: „Dzieło z klasztoru sióstr dominikanek należy do jednych z pierwszych przedstawień malarskich w Polsce poświęconych tematowi siedmiu archaniołów. Jest tym bardziej wyjątkowe, że jako jedyne zawiera w sobie, oprócz atrybutów anielskich, podpisy imion siedmiu duchów". 
partii omawianych rodzimych przedstawień ${ }^{24}$. Do asocjacji motywu oka wpisanego w trójkąt i postaci siedmiu Archaniołów doszło także na obrazie z XVIII w., znajdującym się w kościele parafialnym w Kaszycach ${ }^{25}$ (il. 4). Nie zawsze występujący na przedstawieniach „Siedmiu Archaniołów" motyw $\mathrm{Ocu}$ lus Dei można interpretować jako symbol Bożej Opatrzności. Wpisany w trójkąt może pełnić rolę znaku Trójcy Świętej, adorowanej przez niebieskich duchów. Jednak w wypadku omawianego krakowskiego wizerunku jego wymowa jest jednoznaczna.

Wśród różnorodnych przedstawień „Adoracji Bożej Opatrzności", szczególnie popularnych w sztuce polskiej XVIII stulecia, najczęściej występującym motywem towarzyszącym Bożemu oku ujętemu w trójkąt równoramienny, są wyłaniające się $\mathrm{z}$ chmur dwie dłonie. Na ogół

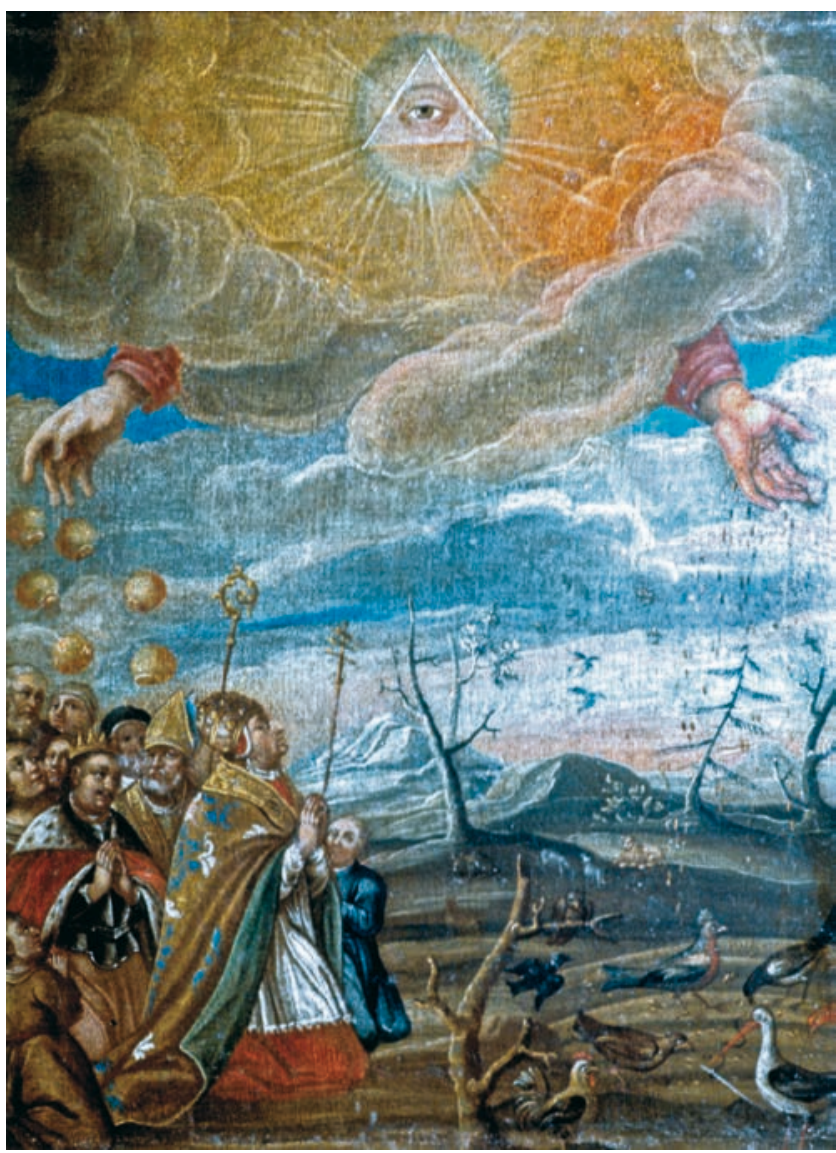

il. 5. Alegoria Bożej Opatrzności, ok. 1700, Kraków, Klasztor SS. Norbertanek na Zwierzyńcu, fot. C. Moisan-Jablonski.

Boża prawica zrzuca ludziom bochny chleba, podczas gdy druga manus Dei sypie ziarno przeznaczone dla ptaków. Schemat ten będziemy spotykać w górnej części prawie wszystkich rodzimych przedstawień: obrazów, malowideł ściennych czy też drzeworytów ${ }^{26}$.

\footnotetext{
24 Nie można także wykluczyć, że rodzime przedstawienia nowożytne mogły być w niektórych wypadkach inspirowane wzorami miniatorskimi z okresu średniowiecza i wczesnej nowożytności, przedstawiającymi postacie archaniołów.

${ }_{25}$ Karta Inwentaryzacyjna NID, opr. J. Stęchły, (woj. podkarpackie), kościół pw. świętych Piotra i Pawła, olej na płótnie, „Adoracja oka Opatrzności”, XVIII w.; por. Stępień-Kirejczyk, op. cit., s. 107-108, il. 95; przedstawienie siedmiu archaniołów z Kaszyc jest prawdopodobnie dziełem tego samego nieznanego artysty, który namalował drugi, nietypowy obraz przechowywany w tym samym kościele, ukazujący tzw. Siedem Świętych Ucieczek; por. K. Moisan-Jabłońska, Polskie i dolnośląskie przedstawienia «Septem Refugia»-mało znanego tematu malarstwa religijnego powstatego w kręgu kultury niemieckiej, w: W kręgu sztuki polskiej i grafiki europejskiej, red. K. Moisan-Jabłońska, Warszawa 2011, s. 157-161.

26 Większe różnice tematyczne i kompozycyjne obserwujemy w dolnej części przedstawień. Autorka obecnie opracowuje ikonografię przedstawień Bożej Opatrzności występujących w polskiej sztuce nowożytnej.
} 


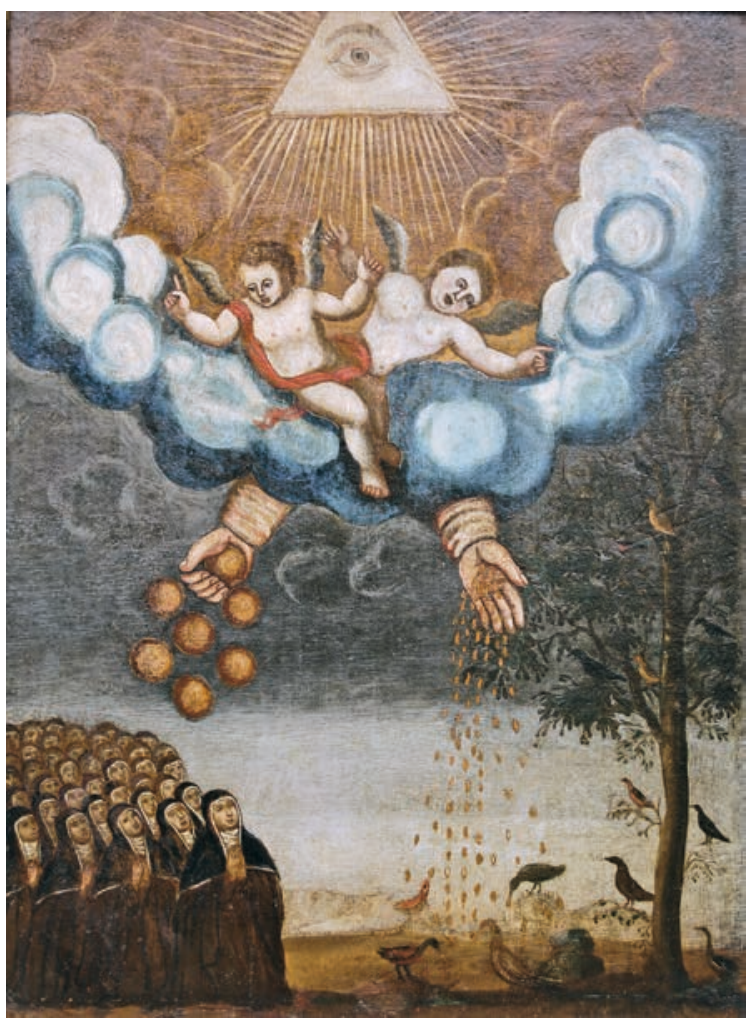

il. 6. Alegoria Bożej Opatrzności, XVIII w., Stary Sącz, Klasztor SS. Klarysek, fot. Archiwum klasztorne.
Należy zaznaczyć, że wizerunki „Bożej Opatrzności” często będą występować w żeńskich klasztorach. Dla przykładu wymieńmy obraz pochodzący z klasztoru norbertanek na Zwierzyńcu w Krakowie $^{27}$ (il. 5), powstały około $1700 \mathrm{r}$. Podczas gdy dextra Dei, wyjątkowo zamiast bochnów chleba, zrzuca otwarte mieszki przeznaczone dla ludzi, druga Boża dłoń rozsiewa ptakom ziarno. Klęczące na pierwszym planie postacie uosabiają wszystkie stany, którymi opiekuje się Boża Opatrzność. Wśród osób zgromadzonych za plecami papieża, biskupa i króla, dostrzegamy oblicza świeckich niewiast oraz mniszek. Jedna $\mathrm{z}$ nich ma na głowie charakterystyczny czarny welon norbertanek. Kolejnym przykładem jest malowidło ścienne umieszczone w jednym z pól kopuły dawnego kościoła cystersek w Owińskach ${ }^{28}$. Namalował je w 1729 r. franciszkański malarz Adam Swach. Symbol Bożej Opatrzności adoruje grupa mniszek

wraz z ksienią dzierżącą pastorał. Nad klęczącymi zakonnicami fruwają różnorodne ptaki oraz unoszą się aniołowie.

Z klasztoru sióstr klarysek w Starym Sączu pochodzi aż kilka przedstawień Bożej Opatrzności. Jeden z obrazów, namalowany w roku 1756, przedstawia symbol Bożej Opatrzności ukazany ponad sceną cudownego rozmnożenia przez Jezusa chleba i ryb ${ }^{29}$.

$\mathrm{Na}$ kolejnym, Boże ręce zrzucają grupie franciszkańskich mniszek bochny chleba a ptakom ziarno ${ }^{30}$ (il. 6). Szczególnie interesujące malowidło z około 1780 r., znajduje

\footnotetext{
27 Katalog Zabytków Sztuki w Polsce, t. IV, Miasto Kraków, cz. VII, Zwierzyniec, Nowy Świat, Pótwsie Zwierzynieckie. Kościoły i klasztory, red. J. Daranowska-Łukaszewska, R. Henoch-Marendziuk, Warszawa 1995, s. 26, il. 149.

${ }^{28}$ Katalog Zabytków Sztuki w Polsce, t. V, Dawne województwo poznańskie, red. T. Ruszczyńska, A. Sławska, z. 20, Dawny powiat poznański, opr. T. Ruszczyńska, A. Sławska, Warszawa 1977, s. 30; Karta Inwentaryzacyjna NID, opr. B. Dembińska, woj. wielkopolskie. Owińska, kościół par. pw. św. Jana Chrzciciela; D. Matyaszczyk, Przesłanie ksieni Joanny Malczewskiej w kościele cysterek w Owińskach, w: Ziemia - Człowiek - Sztuka. Interdyscyplinarne studia nad ziemia. Archeologia, historia, kultura, sztuka, red. U. Mazurczak, Lublin 2015, s. 439-480.

29 Karta Inwentaryzacyjna NID, opr. A. Styczyńska, woj. małopolskie. Olej na płótnie.

30 Karta Inwentaryzacyjna NID, opr. A. Styczyńska, woj. małopolskie. Olej na płótnie, obraz przemalowany, obecnie o charakterze barokowo-ludowym.
} 
się na drzwiach kapitularza ${ }^{31}$ (il. 7). Górna kwatera o kształcie półkolistej arkady ukazuje krzyż i Najświętszy Sakrament jako największe dary Bożej Opatrzności przeznaczone dla świata. Podobnie jak na innych przykładach manus Dei zrzuca bochny chleba zakonnicom a zboże ptakom. Dwie mniszki ukazane po lewej stronie, na tle zabudowy klasztornej to zapewne święte Klara i Kunegunda, których sylwetki zostały powtórzone na skrzydłach drzwi.

Obraz z krakowskiego klasztoru wizytek posiada podobną wymowę jak powyżej wymienione pozostałe malarskie przykłady. Zamiast motywu pary rąk rozsypujących Boże dary, odnajdujemy na nim niebieskich posłańców zaopatrujących zwierzęta i ludzi. Zarówno anioł wysypujący z rogu obfitości sznury pereł oraz różnorodne klejnoty jak i anioł trzymający snopek zboża spełniają wolę Bożej Opatrzności. Pomimo że na obrazie nie odnaj-

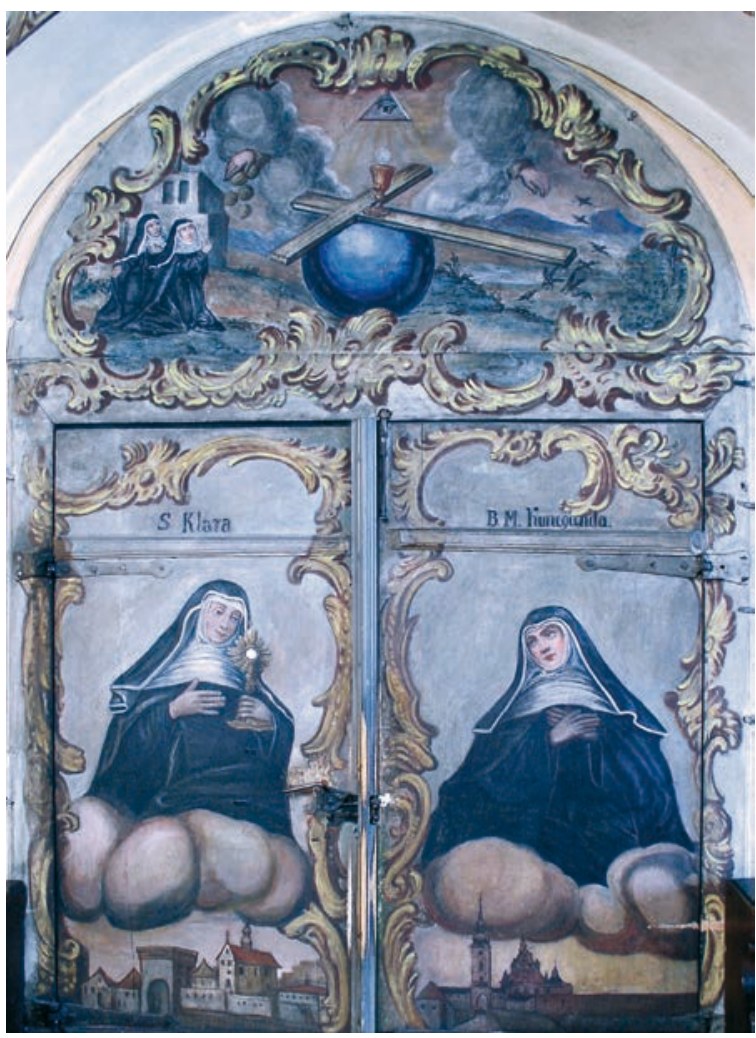

il. 7. Alegoria Bożej Opatrzności, ok. 1780, Stary Sącz, Klasztor SS. Klarysek, fot. Archiwum klasztorne. dziemy, jak na pozostałych zakonnych przykładach, postaci mniszek, przedstawienie z Krowodrzy jawi się jako świadectwo żywego kultu Bożej Opatrzności, a zarazem ufności w Bożą Opiekę ówczesnych mieszkanek krakowskiego klasztoru Zakonu Nawiedzenia Najświętszej Maryi Panny.

\section{The symbolism of the painting Allegory of Divine Providence in the convent of the Sisters of the Visitation in Kraków Summary}

There is an eighteenth-century painting depicting Allegory of Divine Providence in the convent of the Sisters of the Visitation in Kraków. The iconography is unique. In addition to figures of people and animals abandoning themselves to the care of Divine Providence, it also shows the seven archangels. Although the Catholic Church only recognizes three Archangels (Gabriel, Michael and Raphael), portrayals of seven archangels appeared in European art

31 M. Kornecki, Bt. Kinga - pamiątki, obiekty kultu, dzieła sztuki. Inwentarz z terenu Diecezji Tarnowskiej, Tarnów 1990, [nadbitka z „Currendy” nr 1-3/90], s. 15, il. 47; M. Kłos, Ikonografia świętej Kingi w nowożytnej sztuce polskiej i piśmiennictwie religijnym, praca magisterska, promotor: C. Moisan-Jablonski, Warszawa 2010, msps, [biblioteka UKSW], s. 62-63, il. 20. 
at the end of sixteenth century and in the seventeenth and eighteenth centuries, which also showed figures representing Uriel, Barachiel, Sealtiel and Jehudiel. The Reverend Ignacy Tłuczyński also mentions them in a book - on to the subject of angels and the care which angels and heavenly spirits provide to people-published in Kraków in 1677. It would be impossible to have a full understanding of the message conveyed in the Kraków painting without having knowledge of Polish eighteenth-century religious songs devoted to Divine Providence. The dominant motif - which also appears on other Polish paintings depicting Divine Providence - is the portrayal of people and animals together, to whom Providence is offering various gifts.

Keywords: Divine Providence, Painting, Baroque, Seven Archangels, Iconography

Nota o Autorze: dr hab. Christine Moisan-Jablonski, prof. UKSW. Historyk sztuki specjalizuje się w zagadnieniach symboliki sztuki końca XVI, XVII i XVIII wieku. Kierownik Katedry Sztuki Nowożytnej (Instytut Historii Sztuki, UKSW). Redaktor i założycielka serii wydawniczej Polska sztuka kościelna Renesansu i Baroku. Tematy i symbole. Głównym przedmiotem zainteresowań badawczych są nie tylko same dzieła plastyczne lecz także staropolskie piśmiennictwo religijne będące istotnym elementem interdyscyplinarnych analiz porównawczych. Kolejne obszary poszukiwań obejmują badania nad związkami grafiki zachodnioeuropejskiej i malarstwa polskiego, sposobami obrazowania archetypicznych pojęć (np. żywioły, pory roku, zmysły) oraz relacją słowa i obrazu w grafice europejskiej XVII i XVIII stulecia. 